\title{
UNIVERSITYOF
}

FORWARD

THINKING

WESTMINSTER用

WestminsterResearch

http://www.westminster.ac.uk/westminsterresearch

Race, Debt and the Welfare State

Pitcher, B.

This is an author's accepted manuscript of an article published in New Formations (87) 47-63 2016. The final definitive version is available online at:https://dx.doi.org/10.3898/NEWF.87.3.2016

The WestminsterResearch online digital archive at the University of Westminster aims to make the research output of the University available to a wider audience. Copyright and Moral Rights remain with the authors and/or copyright owners.

Whilst further distribution of specific materials from within this archive is forbidden, you may freely distribute the URL of WestminsterResearch: ((http://westminsterresearch.wmin.ac.uk/).

In case of abuse or copyright appearing without permission e-mail repository@westminster.ac.uk 
This is a pre-print version of an article published as Pitcher, B (2016) 'Race, Debt and the Welfare State', New Formations, 87: 47-63.

\section{Race, debt and the welfare state}

Obviously, we are talking about a negative subjection, the most obvious indication that flows of knowledge, action, and mobility, although continually solicited, lead only to repressive and regressive subjectivation $^{1}$

The tendencies in favour of general equality most decisively reject money, even though it is by nature a basically democratic levelling social form that excludes any specific individual relationships ${ }^{2}$

In this article I want to explore how the figure of debt might illuminate the racial politics of welfare in neoliberal Britain. I begin by giving a reading of the simultaneous unfolding of postwar race politics and the Beveridgean welfare state, and then turn to speculate on the interpellative appeal of neoliberal debt to minoritized subjects who have in certain respects been de facto excluded

\footnotetext{
${ }^{1}$ Maurizio Lazzarato, Signs and Machines: Capitalism and the Production of Subjectivity, Los Angeles, Semiotexte, 2014, p10.

${ }^{2}$ Georg Simmel, The Philosophy of Money (third edition), London, Routledge, 2004, p447.
} 
This is a pre-print version of an article published as Pitcher, B (2016) 'Race, Debt and the Welfare State', New Formations, 87: 47-63.

from a prevailing regime of welfare citizenship. In particular, this article

considers the ways in which household debt might, even as it increases social inequality, simultaneously produce ideas about equality and futurity, as well as gesture towards the possibility of post-national forms of identity and belonging. If we are to challenge the lowest-common-denominator logics of 'capitalist realism' it is necessary to develop orientations to the economic that are as convincing as the popular stories that circulate about the operations of the neoliberal marketplace, and which are as meaningful as the social relations they play a part in constituting. Rather than reproduce the racialized model of welfare citizenship that is implicit to the 'defence' of the postwar welfare state, I suggest that there are elements of neoliberal market relations that might themselves serve as a more substantial basis for expressions of racial equality. There are, in other words, things that we could learn from neoliberal debt regimes in order to develop a more egalitarian future-oriented politics of social welfare and economic redistribution.

\section{Race and postwar welfare citizenship}

As austerity exerts itself as a political device upon the institutions of the British welfare state, the immediate post war conjuncture feels simultaneously resonant and far away. Even as the aesthetics of austerity culture become a central reference point in British cultural life, ${ }^{3}$ the founding of the welfare state is distantiated as an historical event, set in the middle of a broad-brush twentieth century as-seen-from the second decade of the twenty-first. It is this

\footnotetext{
${ }^{3}$ Rebecca Bramall, The Cultural Politics of Austerity: past and present in austere times, Basingstoke, Palgrave Macmillan, 2013.
} 
This is a pre-print version of an article published as Pitcher, B (2016) 'Race, Debt and the Welfare State', New Formations, 87: 47-63.

combination of proximity and distance that facilitates recognition of the simultaneity of the welfare state and the phenomenon of postwar immigration, and encourages reflection on the relationship between the politics of welfare and the politics of race.

The summer of 1948 has a particular resonance in British popular memory. On June 22 some 500 or so Jamaican migrants disembarked from the Empire Windrush at London's Tilbury Docks, symbolic of the first wave of postcolonial immigration and the retrenchment of Britain's empire. Within a fortnight, July 5 saw the inauguration of Britain's National Health Service (NHS), cornerstone of its postwar welfare state. Yet these events, and the significant shifts in British history they played a part in bringing about, are rarely thought together. It is not simply a temporal coincidence that 1948 saw the arrivals of both Empire Windrush and the NHS. Both were characterized by new compacts in citizen-state relations. Taking their lead from the Beveridge report of 1942, the architects of the welfare state advanced a notion of citizenship as universal entitlement. At the same time British colonial subjects (already de jure British citizens) were simultaneously given the right under the British Nationality Act of 1948 to travel to and work in the UK, and thus to become part of the new material-symbolic nexus of welfare citizenship. While 1948 can be retrospectively conceived as a moment of considerable social and cultural transformation in the character and complexion of British citizenship, it would be incorrect to think about the racial and welfare transformations of the postwar moment as elements of a single coherent plan or programme on the part of Clement Attlee's presiding Labour government, or as indicating a 
This is a pre-print version of an article published as Pitcher, B (2016) 'Race, Debt and the Welfare State', New Formations, 87: 47-63.

widespread cultural consensus about the relationship between the two.

Despite the longstanding strand in anti-racist rhetoric that foregrounds the role of commonwealth immigrants in servicing welfare Britain (particularly in staffing the NHS), there is no easy connection between these phenomena. Indeed, it is often the case that race and welfare are placed in conflict with one another. As John Clarke has noted, accounts of welfare state universalism 'repress evidence of a whole variety of exclusions and subordinations', ${ }^{4}$ not least of which are the implicit conditions placed on welfare citizenship by an overdetermining nationalism. Though there is no real evidence for 'welfare magnet arguments', ${ }^{5}$ the welfare state is commonly evoked in immigration debate as a signifier of that which migrants covet and place under threat. Such rhetoric has a long history: as early as 1958, for example, the Tory peer the Marquess of Sailsbury (and later Chairman of the anti-decolonization pressure group the Monday Club) was worrying aloud from his seat in the House of Lords that an open door to Commonwealth immigration would cause the imminent breakdown of 'the Welfare State, of which we are so proud' ${ }^{6}$ Notwithstanding a long sequence of immigration restrictions put in place from 1962 onwards, populist complaints have

\footnotetext{
${ }^{4}$ John Clarke, Changing Welfare, Changing States: new directions in social policy, London, Sage, 2004, p14.

${ }^{5}$ Trude Sundberg, 'Attitudes to the Welfare State: A Systematic Review Approach to the Example of Ethnically Diverse Welfare States', Sociological Research Online, 19, 1, (2014), §5.6. Available at: http://www.socresonline.org.uk/19/1/28.html [21.10.14].

${ }^{6}$ Hansard, HL Deb, vol 212, 19 November (1958), \$670. Available at: http://hansard.millbanksystems.com/lords/1958/nov/19/colour-prejudice-andviolence\#S5LV0212P0_19581119_HOL_54 [02.10.15].
} 
This is a pre-print version of an article published as Pitcher, B (2016) 'Race, Debt and the Welfare State', New Formations, 87: 47-63.

increasingly insisted that migrants intend to 'exploit our lavish welfare state".

When this lavishness is evidently in question, governments of both left and right have pandered to racist complaints of immigrant and refugee advantagetaking, council house queue-jumping and benefit benefiting, and in doing so have found 'a convenient scapegoat for a creaking welfare state'. ${ }^{8}$

Longstanding racialized tensions around welfare and immigration are registered in contemporary accounts of 'welfare chauvinism' which reckon that immigrants have been accorded the status of 'the new undeserving poor'. 9

While it is possible to make an argument that these racialized exclusions have frequently derived from the cynical calculations of populist political actors, there's the prospect here of profounder processes at work in articulations of welfare citizenship. In so far as citizenship is never a question only of formal, abstract or legal entitlement but always involves normative conceptions of identity, it is plausible to suggest that welfare state imaginaries have long been informed by racially exclusive discourses of national belonging. As with the Swedish welfare concept of the folkhem, ${ }^{10}$ national identity and social rights in Britain have had a close and mutually reinforcing relationship.

${ }^{7}$ Daily Express, 'Migrants take advantage of generous welfare state', 20 July, 2015. Available at:

http://www.express.co.uk/comment/expresscomment/592493/Immigrantsimmigration-crisis-Calais-benefits-doctors-NHS [02.10.15].

8 Daniel Trilling, Bloody Nasty People, London, Verso, 2012, p93.

${ }^{9}$ Tim Reeskens and Wim van Oorschot, 'Disentangling the "New Liberal Dilemma": On the relation between general welfare redistribution preferences and welfare chauvinism', International Journal of Comparative Sociology, 53, 2, (2012), p121.

${ }^{10}$ Andrzej Marcin Suszycki, 'Nationalism in Sweden and the EU Membership', in Ireneusz Pawel Karolewski and Andrzej Marcin Suszycki (eds) Nationalism and European Integration, London, Continuum, 2007, p.86. 
This is a pre-print version of an article published as Pitcher, B (2016) 'Race, Debt and the Welfare State', New Formations, 87: 47-63.

Despite internationalist, anti-imperialist and anti-racist currents that suggested alternative directions, nineteenth and twentieth-century movements for social and economic justice in Britain were inflected by a racialized nationalism, and the gains of the British welfare state were not exempt from this. In his history of race and class in twentieth-century Britain, Satnam Virdee suggests that the incorporation of working class whites into welfare citizenship was contiguous with a systematic racism, such that '[t]he golden age of welfare capitalism and the social democratic settlement was also the golden age of white supremacy'. ${ }^{11}$ The unplanned coincidence of the welfare state and postwar immigration - and the absence of any real thinking through of how the former might accommodate the latter - mean that racialized nationalism was the default setting of mid-century welfare imaginaries: ideas of race and nation 'both underwrote Fabian socialism and were embedded in the Beveridge reforms'. ${ }^{12}$ Given that the British Nationality Act of 1948 was prompted by the short-term issue of domestic labour shortage rather than an intentional long-term experiment in racial demographics, it can be argued that its apparent openness to difference was both unintentional and unwanted. Ironically, the founding gesture of multicultural Britain as we know it today was made by a political establishment whose normative conception of citizenship was still largely predicated on the fantasy of Britain as a white nation. As Kathleen Paul suggests, despite the façade of formal equality, policy-makers in the postwar decades 'perceived emigrating UK citizens, immigrating

\footnotetext{
11 Satnam Verdee, Racism, Class and the Racialized Outsider, Basingstoke, Palgrave Macmillan, 2014, pp.98-9.

12 Gail Lewis, 'Welfare settlements and racialising practices', Soundings, 4, (1996), p112.
} 
This is a pre-print version of an article published as Pitcher, B (2016) 'Race, Debt and the Welfare State', New Formations, 87: 47-63.

continental and Irish aliens, and migrating subjects of color as belonging to different communities of Britishness. ${ }^{13}$ During this period a racialized notion of 'indigenousness' remained a 'significant political calculation' in Labour Party politics. $^{14}$

Alongside a range of other social norms that were written into the welfare state, whiteness was therefore a hidden particularity concealed within the discourse of universal welfare citizenship. When we conceive of citizenship not as an abstract ideal but as 'a process, social relation or orientation that can be precarious and that must be repeatedly asserted and attained', ${ }^{15}$ then the uneven distribution of its symbolic and material resources become readily apparent. ${ }^{16}$ While the terms of welfare citizenship for minority subjects have been by no means static, the welfare state has always been a racialized institution: writing in the mid 1990s about the fields of education and social work, Gail Lewis remarks that 'in charting the history of welfare exclusion and marginality it is also possible to narrate a history of the reconstitution of the 'coloured immigrant' into her/his contemporary position as an 'ethnic minority'. ${ }^{17}$ It is no coincidence that the progressive political struggles in the 1980s and 90s around race, gender, sexuality, and disability contributed to debates about a 'crisis' of the welfare state, challenging as they did 'the

\footnotetext{
${ }^{13}$ Kathleen Paul, Whitewashing Britain: Race and Citizenship in the Postwar Era, New York, Cornell University Press, 1997, pxii.

${ }^{14}$ Caroline Knowles, Race, Discourse and Labourism, London, Routledge, 1992, p97.

${ }^{15}$ Andrea Muelebach, The Moral Neoliberal: Welfare and Citizenship in Italy, Chicago, University of Chicago Press, 2012, p19.

${ }^{16}$ Gail Lewis, Citizenship: Personal Lives and Social Policy, Milton Keynes, The Open University, 2004, p10.

17 Lewis, 1996, op. cit., p111.
} 
This is a pre-print version of an article published as Pitcher, B (2016) 'Race, Debt and the Welfare State', New Formations, 87: 47-63.

comfortable imaginary relationship of people, state and social welfare'. ${ }^{18}$ Yet however significant new social movements were in their critique of the racialized welfare state, cultural nationalism has never been adequately displaced at the normative core of British welfare citizenship. Though the US model of welfare citizenship is hardly one to emulate, it provides a useful contrast here: while the civil institutionalization of racial inequality eventually shaped the terms for the development of America's civil rights struggles, the more longstanding formal equalities of citizenship in Britain have meant that the informal terms of British citizenship have not benefited from critical interrogation in quite the same ways. Such is the insidiousness of the universal. Although antiracisms have repeatedly exposed the racialized lineaments of state and civil society, governmental crisis management has most commonly responded in a piecemeal fashion: most often, it has been community rights not civil rights that have served to smooth out the worst excesses of racial inequality. ${ }^{19}$

In the twenty-first century the inaugural moment of the British welfare state continues to be heralded as its 'golden age'. ${ }^{20}$ Such evocations will often get caught up with a monocultural fantasy of 1950s Britain, serving as a benchmark against which subsequent demographic changes are measured. Perceived social or cultural problems are then expressed in terms of the

\footnotetext{
18 John Clarke, Gordon Hughes, Gail Lewis and Gerry Mooney, 'introduction', in G. Hughes (ed.) Imagining Welfare Futures, London, Routledge, 1998, p9. ${ }_{19}$ Gerd Baumann, The Multicultural Riddle: Rethinking National, Ethnic and Religious Identities, London, Routledge, 1999, p13.

${ }^{20}$ Daniel Wincott, 'The (Golden) Age of the Welfare State: interrogating a conventional wisdom', Public Administration, 91, 4, (2013), pp 806-22.
} 
This is a pre-print version of an article published as Pitcher, B (2016) 'Race, Debt and the Welfare State', New Formations, 87: 47-63.

extent to which they have departed from the foundational conditions of the welfare state. And so we get commentators like David Goodhart, editor of Prospect magazine, expressing concern with the ways in which cultural diversity undermines the social solidarities that sustain the values of the welfare state. ${ }^{21}$ Elsewhere, the authors of a study of East London since the late 1950s conjure a homogenous 'white working class' as the historical subjects of the 'golden age', now legitimately resentful of the way an 'old mutualist' welfare regime has been displaced by a 'something-for-nothingsociety, in which rights to receive support have manifestly overtaken reciprocal obligations to make contributions' ${ }^{22}$ Although it is the contributionbased element in welfare entitlement that is the nominal focus of such complaints (supposedly focused on migrants and not racialized minorities per se), this is a fulcrum that works to undermine universal welfare provision in general. As soon as the question opens up as to degrees of entitlement on the basis of longevity of contribution or residence, we move onto a terrain whereby the political community is always under threat of being compromised by the presence of outsiders, and where in practice white people will tend to have an automatic claim to priority as the ur-community of that 'golden age'. In critiques such as these, we are arguably witness not so much to a retrenchment of the welfare state's universal model of citizenship as the continuing unfolding of its implicit racial investments.

${ }^{21}$ David Goodhart, 'Too Diverse?', Prospect, 96, 2, (2004), pp.30-7. 22 Geoff Dench, Kate Gavron and Michael Young, The New East End: Kinship, Race and Conflict, London, Profile Books, 2006, p207. 
This is a pre-print version of an article published as Pitcher, B (2016) 'Race, Debt and the Welfare State', New Formations, 87: 47-63.

More recent developments in British politics suggest an ongoing continuity in the way the racial welfare state has been practiced and imagined. Following New Labour's embrace of communitarian thinkers like Robert Putnam and Amitai Etzioni, the tendency known as Blue Labour, led by Labour peer Maurice Glassman, is characterized by a nostalgic articulation of collectivity, morality and citizenship. Policies put in place between $2010-15$ by the Conservative-led coalition government intensified the policing of welfare entitlement, effectively requiring front-line NHS medical treatment to serve as a checkpoint for the UK Border Agency. The new Tory regime's response to the 2015 European 'refugee crisis' paints a familiar picture of struggling 'schools and hospitals and core infrastructure' and a 'cohesive society' under threat. $^{23}$ In the realm of housing policy, it is widely recognized that forms of 'austerity urbanism'24 like the capping of benefit payments have a disproportionate impact on minority communities. ${ }^{25}$ Rather than being residual phenomena, it is plausible that in recent decades there has been an accentuation and acceleration of implicitly racialized distinctions in welfare citizenship, as Britain experiences the playing out of a widespread global shift in national imaginaries 'from a state-based and thus political identification with nationality to a culture-based concept of the nation as a site of integrated

${ }^{23}$ Independent, 'Theresa May's Speech to the Conservative Party Conference - in full', 6 October. Available at:

http://www.independent.co.uk/news/uk/politics/theresa-may-s-speech-to-theconservative-party-conference-in-full-a6681901.html [07.10.15].

${ }^{24}$ Chris Hamnett, 'Shrinking the welfare state: the structure, geography and impact of British government benefit cuts', Transactions of the Institute of British Geographers, 39, 4, (2014), p491.

${ }^{25}$ DWP, Household Benefit Cap Equality Impact Assessment, 2011, Available at: www.parliament.uk/documents/impact-assessments/IA11-041A.pdf [18.08.14]. 
This is a pre-print version of an article published as Pitcher, B (2016) 'Race, Debt and the Welfare State', New Formations, 87: 47-63.

social membership', ${ }^{26}$ where issues relating to citizenship and welfare come to be addressed 'as matters of culture and ethnicity' 27 and collective goods are 'authorized by a shared identity'. ${ }^{28}$ Despite the pluralistic character of contemporary Scottish nationalism, moves towards fiscal independence within Britain's constituent nations will most likely accentuate culture's role in underwriting welfare. Although there are undoubtledly strong cosmopolitan tendencies in demotic iterations of British national culture, the backwardlooking tendencies I have surveyed here suggest that welfare continues to be marked by anachronistic conceptions of entitlement and belonging. While the British welfare state has adapted, albeit slowly and inadequately, to other social and cultural changes - consider how the Beveridge report assumes female dependence on the male wage ${ }^{29}$ - race presents a persistent challenge to its supposedly universal character.

The racialization of welfare imaginaries poses some important questions, then, for political projects interested in defending the idea of the British welfare state and working on the powerful attachments and investments that palpably still exist for it. Clearly the figuration of a straightforward return to an anachronistic model of welfare citizenship is undesirable given the implicit racial investments I have just glossed, and so such projects have to do quite a

\footnotetext{
${ }^{26}$ Lauren Berlant, The Queen of America Goes to Washington City, Essays on Sexual Citizenship, Durham, Duke University Press, 1997, p3.

${ }^{27}$ Ferruh Yilmaz, 'From immigrant worker to Muslim immigrant: challenges for feminism', European Journal of Women's Studies, 22, 1, (2015) p12.

28 Jean Comaroff and John Comaroff, Theory from the South or, How EuroAmerica is Evolving Towards Africa, London, Paradigm Publishers, 2012, p68.

${ }^{29}$ Rosemary Sales, 'The deserving and undeserving? Refugees, asylum seekers and welfare in Britain', Critical Social Policy, 22, 3, (2002), p456.
} 
This is a pre-print version of an article published as Pitcher, B (2016) 'Race, Debt and the Welfare State', New Formations, 87: 47-63.

bit of work to adequately reimagine welfare citizenship if it is to be fit for purpose for twenty-first century multicultural Britain. If the politics of austerity is - as critiques of neoliberal retrenchment have long suggested - indeed engaged in the 'dismantling' of the welfare state, ${ }^{30}$ a politically progressive challenge to this practice should involve no simple reassembly of component parts. Such mechanistic metaphors fail, of course, to capture not only the problems and imperfections of the postwar welfare state, but also the need to think about the mutable character of welfare as describing social processes that necessarily involve transformations across space and time. Opposition to 'dismantling' must involve attempts to reform and restructure in some fundamental ways the dominant logics of welfare citizenship.

As a contribution to this project, what I want to do in the rest of this article is to take seriously the possibility that neoliberal attacks, displacements and replacements of welfare might in some quarters have some significant purchase and appeal. As Michael A. Kaplan suggests of liberal imaginaries, to advance a critique of neoliberalism requires 'a nuanced understanding of its rhetorical efficacy'. ${ }^{31}$ If, as I have just suggested, the putative universalism of welfare citizenship conceals hidden particularisms, then how might posited alternatives to the welfare state appear to certain subjects to provide a more egalitarian model of social relations? As debt becomes increasingly central to

\footnotetext{
${ }^{30}$ Paul Pierson, Dismantling the Welfare State? Regan, Thatcher and the Politics of Retrenchment, Cambridge, CUP, 1994.

${ }^{31}$ Michael A. Kaplan, Friendship Fictions: The Rhetoric of Citizenship in the Liberal Imaginary, Tuscaloosa, The University of Alabama Press, 2010, p4.
} 
This is a pre-print version of an article published as Pitcher, B (2016) 'Race, Debt and the Welfare State', New Formations, 87: 47-63.

the economic organization of the industrialized world, ${ }^{32}$ we appear to be moving away from a model of citizen-state relations predicated on welfare to one based on household debt. As neoliberalism encourages its subjects to self-invest as 'financialized human capital', ${ }^{33}$ then might indebtedness have a particular appeal to minority subjects who have historically been marginalized in a prevailing regime of welfare citizenship? As a way in to the consideration of these questions, I want first to address the relationship between racialized minorities and neoliberal culture in contemporary Britain.

\section{Minorities and neoliberal culture}

In an article for this journal, Paul Gilroy outlines the 'seductions of a vernacular neoliberalism', ${ }^{34}$ specifically the appeal of aspirational individualism, bolstered by the rhetoric of self-improvement and selfresponsibility, to racialized minorities in Britain. He ends by asking 'whether an authentic liberatory moment might [...] reside in postcolonial peoples and minority ethnic groups being just as selfish, ignorant, right-wing and conservative as everybody else? ${ }^{, 35}$ Gilroy's cynical provocation that this

\footnotetext{
32 Andrew Ross 'The Politics of Debt Resistance', New Labor Forum, 22, 3, 2013, pp.12-15.

${ }^{33}$ Wendy Brown, Undoing the Demos: Neoliberalism's Stealth Revolution, New York, Zone Books, 2015, p. 33.

34 Paul Gilroy, '“....We Got to Get Over Before We Go Under...” Fragments for a History of Black Vernacular Neoliberalism', New Formations, 80-81, 2013, p26.

35 Ibid., p36.
} 
This is a pre-print version of an article published as Pitcher, B (2016) 'Race, Debt and the Welfare State', New Formations, 87: 47-63.

moment might be read 'as a new index of Britain's integration' ${ }^{36}$ is a pertinent observation, and is worth considering in the context of the present discussion. The obvious recognition that neoliberal orientations are not simply imposed from without onto racialized minorities but also involve forms of participation and collaboration ${ }^{37}$ provides an opportunity to think about some of the factors that might be involved in neoliberal culture's appeal as an alternative to the welfare state.

There is perhaps some truth in ex-Prime Minister John Major's recent claim that the 'guts and the drive' of postwar immigrants can be attributed to a 'very Conservative instinct' to 'better themselves and their families' ${ }^{38}$ so long as this conservatism is largely understood in anti-statist (rather than pro-Tory) terms.

Gargi Bhattacharyya suggests that ostensible passivity towards to the encroachment of neoliberalism is explained by a 'disappointment or scepticism towards the state' amongst minorities in Britain, and a 'widespread cynicism towards official solutions'. Strategies of self-reliance and the pursuit of community-focused practices are the means by which some racialized minorities have bypassed unproductive engagement with the welfare state. ${ }^{39}$ The exponential rise of a phenomenon like 'prosperity theology' ('the

\footnotetext{
36 Ibid.

${ }^{37}$ Lester K. Spence, 'The neoliberal turn in black politics', Souls: A Critical Journal of Black Politics, Culture and Society, 14, 3-4, pp139-59.

38 Jessica Elgot, 'John Major Praises "Guts and Drive" Of Immigrants, And Says They Have "Very Conservative Instinct", 13 August 2014. Available at: http://www.huffingtonpost.co.uk/2014/08/13/john-majorimmigration_n_5673844.html [18.08.2014].

${ }^{39}$ Gargi Bhattacharyya, 'Racial Neoliberal Britain?', in N. Kapoor, V. S. Kalra and J. Rhodes (eds) The State of Race, Basingstoke, Palgrave Macmillan, 2013, pp45-6.
} 
This is a pre-print version of an article published as Pitcher, B (2016) 'Race, Debt and the Welfare State', New Formations, 87: 47-63.

organization of religion around the goal of future prosperity') amongst the African Christian diaspora ${ }^{40}$ deserves to be understood in this context. In Gilroy's analysis, the systematic racist experience of 'being denied recognition as an individual' strengthens the appeal of neoliberalism's 'extreme individualism'. ${ }^{41}$ The entrepreneurial path of autonomy and self-employment has long provided an alternative for those who have otherwise been shut out of the networks, relations and institutions of power and privilege. ${ }^{42}$ The relative visibility of minorities in lower-ranking local government, health and care sector employment does not mitigate significant absences in the higher echelons of the institutions of the welfare state. ${ }^{43}$ Indeed, there is a sense in which minorities' widespread public sector employment in the postwar welfare state's so-called 'golden age' tells a generational story about relative disadvantage and necessarily modest ambition from which subsequent generations are understandably keen to distance themselves.

The neoliberal orientations I have just sketched out are also part of a story about the rise of the black middle-class, surburbanization, and an accompanying culture of aspiration. ${ }^{44}$ As in the United States, where access

\footnotetext{
${ }^{40}$ Bev Skeggs, 'Values beyond value? Is anything beyond the logic of capital?', The British Journal of Sociology, 65, 1, (2014), p2.

${ }^{41}$ Gilroy, op. cit., p35.

42 Javed Hussain, Jonathan Scott and Paul Hannon, 'The new generation: characteristics and motivations of BME graduate entrepreneurs', Education and Training, 50, 7, 2008, p. 583.

${ }^{43}$ See, for example, Denis Campbell, 'NHS boss Simon Stevens criticises lack of diversity in management', Guardian, 21 May 2014. Available at: http://www.theguardian.com/society/2014/may/21/nhs-boss-simon-stevenscriticises-lack-diversity-management [21.10.14].

${ }^{44}$ See Tim Butler and Chris Hamnett, Ethnicity, Class and Aspiration: Understanding London's New East End, Bristol, Policy Press, 2011.
} 
This is a pre-print version of an article published as Pitcher, B (2016) 'Race, Debt and the Welfare State', New Formations, 87: 47-63.

to commodities and participation in consumer culture have proven to be key sites in the struggle for racial equality, ${ }^{45}$ the marketplace has and continues to facilitate forms of social citizenship that may rival, supplement or replace more official versions. Class mobility is a possibility for some even as free markets reduce the average prospects for minorities as a whole. In the US, commentators lament the 'erosion of a black public sphere'46 and chart the emergence of new forms of black politics that make a distinct and intentional break with the civil rights tradition. ${ }^{47}$ While in Britain a black public sphere has only ever been inchoate, there is a definite shift in the register of minority politics where incorporation has resulted in certain trade-offs that have been played out in state institutions and public bodies: consider, for example, the way in which the dedicated Commission for Racial Equality was so neatly folded into the underfunded Equality and Human Rights Commission. ${ }^{48}$ Middle-class minorities can be understood in the context of what David Theo Goldberg calls 'the postracial contemporary ${ }^{49}$ where dominant narratives of official multiculture depend upon and feed off the social and economic success of a small tranche of visible minorities.

${ }^{45}$ Roopali Mukherjee, 'Bling Fling: Commodity Consumption and the Politics of the "Post-Racial"', in M. G. Lacy and Kent A. Ono (eds), Critical Rhetorics of Race, New York, New York University Press, 2011, p184.

${ }^{46}$ Robin D. G. Kelley 'Neoliberalism's Challenge', Boston Review, 2012. Available at: http://www.bostonreview.net/challenge-neoliberalism [21.10.14]. ${ }^{47}$ Ben Pitcher, 'Obama and the Politics of Blackness: anti-racism in the "postblack" conjuncture, Souls, 12, 4, pp313-22.

${ }^{48}$ Sylvia Walby, Jo Armstrong and Sofia Strid, 'Intersectionality and the Quality of the Gender Equality Architecture', Social Politics, 19, 4, (2012). ${ }^{49}$ David Theo Goldberg, 'The Postracial Contemporary' in Kapoor et al., op. cit. 
This is a pre-print version of an article published as Pitcher, B (2016) 'Race, Debt and the Welfare State', New Formations, 87: 47-63.

From a certain position of critique, the contradictions of the postracial contemporary might be understood and lamented as involving 'a relation of attachment' among minority subjects 'to compromised conditions of possibility'. ${ }^{50}$ Yet while there may be currency in the charge that some minority elites have colluded in the further entrenchment of 'intra-racial inequality', ${ }^{51}$ and that minorities might have 'most to lose from neoliberal practices', ${ }^{52}$ it is premature to reduce the attractions of neoliberal culture to some form of false consciousness, or to only conceptualize minorities as the constitutive limit of neoliberal subjectivity. ${ }^{53}$ We might, I want to suggest, make a reading of Gilroy's ‘vernacular neoliberalism' amongst minority subjects as at least in part produced through the failure of more egalitarian and redistributive welfare imaginaries to shed their racial exclusivity. It is the left's attachment to such imaginaries that we might, therefore, better understand in terms of Berlant's 'cruel optimism'. Such a perspective should simultaneously remind us that the critique of neoliberal practice begins on the wrong foot if it invests in a fantasy of the entrepreneurial minority as the neoliberal subject par excellence. I want in the section that follows to extend the idea that 'vernacular neoliberalism' amongst minoritized subjects in contemporary Britain might give a particular cadency to the accumulation of household debt. It will be my suggestion that a focus on debt could provide us with some ways into understanding what neoliberal markets may offer that the welfare state does not, and that we might seek to borrow elements of neoliberal culture in

\footnotetext{
50 Lauren Berlant, 'Cruel Optimism', Differences, 17, 3, (2006), p21.

51 Spence, op. cit., p146.

52 Bhattacharyya, op. cit., p46.

53 Skeggs, op. cit., p10.
} 
This is a pre-print version of an article published as Pitcher, B (2016) 'Race, Debt and the Welfare State', New Formations, 87: 47-63.

our 'defence' of the welfare state and in attempts to elaborate more racially egalitarian versions of or alternatives to welfare citizenship.

Two caveats are necessary before I do this. Firstly, l'd like to foreground the sense in which this is a speculative discussion, developed out of the two arguments this article has so far glossed: to acknowledge the racialization of welfare citizenship in Britain and, relatedly, the differential positioning of some minority subjects towards neoliberal culture, is to open up the possibility that neoliberal debt culture may provide a meaningful substitute to the welfare state for some minoritized Britons. I do not set out to provide an empirical account, but rather to advance some necessarily provisional ideas about the potentially attractive features of indebtedness. Secondly, I want to stress that the example I will elaborate below - the imposition of debt culture in British Higher Education (HE) - has its own specificity, and should not be taken for an argument about the working of debt in general. Although I hope that this example might have wider relevance to understanding the relationship between debt, welfare citizenship and the British welfare state, it has some special characteristics: despite an apparent ideological convergence between business and state in neoliberal culture, there remains a great deal of difference between public and private institutions of debt, between student loans and payday loans. While it should be clear that I am in no way attempting to exonerate neoliberal debt culture as a just and viable alternative to the welfare state, I am interested here in challenging the self-evidence of claims that debt is '[o]bviously [...] a negative subjection' that 'leads only to 
This is a pre-print version of an article published as Pitcher, B (2016) 'Race, Debt and the Welfare State', New Formations, 87: 47-63.

repressive and regressive subjectification, ${ }^{, 54}$ in the belief that such generalized accounts of indebtedness flatten out the 'innumerable ways in which different financial instruments are organized, encountered, and come to resonate with daily life', ${ }^{55}$ including, potentially, the complex roles they might play in processes of racial formation.

\section{The equality of debtors}

In The Making of the Indebted Man, Maurizio Lazzarato describes the neoliberal attack on welfare states, and the replacement of social rights with social debts. ${ }^{56}$ Lazzarato's account of these transformations is particularly strong in its descriptions of the production of indebted subjects. As the disciplined subjects of welfare states are replaced by the debtor subjects of neoliberal control societies, individualized debt becomes the paradigmatic social relation, and cynical entrepreneurialism erodes the horizontal solidarities of welfare democracy. Capitalism's new subjective regime is testament to the power of debt as a structuring force and, consequently, the sheer ubiquity of neoliberal relations. As Lazzarato writes, 'the condition of the indebted man [sic] now occupies the totality of public space'. ${ }^{57}$ Debt is, in his

\footnotetext{
${ }^{54}$ Lazzarato, 2014, op. cit., p10.

55 Joe Deville and Gregory J Seigworth 'Everyday Debt and Credit', Cultural Studies, 29, 5-6, (2015), p.619.

${ }^{56}$ Maurizio Lazzarato, The Making of the Indebted Man: An Essay on the Neoliberal Condition, Amsterdam, Semiotext(e), 2012.

57 lbid., p38.
} 
This is a pre-print version of an article published as Pitcher, B (2016) 'Race, Debt and the Welfare State', New Formations, 87: 47-63.

analysis, the 'universal power relation to which every individual in capitalist networks of accumulation is subjected' ${ }^{58}$

It is in recognition of debt's totalizing dominance that it becomes possible to build a crucial supplementary account of neoliberalism's interpellative appeal, for the universalization of debt relations brings with it a semblance of equal treatment. Initially we might understand this in terms of social class. While of course the unequal resources of debtor subjects makes notional equality illusory (for indebtedness is always shorter and cheaper and therefore qualitatively different for those with more economic resources), I want to suggest in what follows that the universal burden of indebtedness can give the impression of a kind of social levelling that was perhaps less evident in the case of the (actually redistributive) welfare state. The resonance of debt regimes to working class subjects is, I will suggest, to some extent predicated on that powerful claim to equality and entitlement based on the abstract quality of money: the notion that one's money is as good as anyone else's. The political proponents of neoliberal debt culture in Britain appear to have made impressive use of debt's intelligibility. Like the fiction of market freedom, it "provides its subjects with a "lived" "imaginary relation" to their real conditions of existence'. ${ }^{59}$ It is the uncomfortable fact of money's 'qualitatively communistic character ${ }^{\prime 60}$ that, I want to suggest, surely played a part in

58 James Muldoon 'Lazzarato and the Micro-Politics of Invention', Theory, Culture and Society, 31, 6, (2014), pp57-76.

59 Stuart Hall, The Neo-Liberal Revolution, Cultural Studies, 25, 6, (2011), p716.

${ }^{60}$ Simmel, op. cit., p445. 
This is a pre-print version of an article published as Pitcher, B (2016) 'Race, Debt and the Welfare State', New Formations, 87: 47-63.

underwriting the widespread acceptance of recent transformations in British higher education.

The financing of British HE has shifted fairly rapidly from a model of general taxation with maintenance grants in the late 1980s to a loan-based model requiring students to pay annual tuition fees, currently set in England at $£ 9,000$. $^{61}$ The widening of HE provision has gone hand in hand with its neoliberalization, and indebtedness now describes the terms of participation, inaugurating in Britain what American commentators have called an 'indentured class' of student debtors ${ }^{62}$. The last five years have seen an intensified process of privatization, deregulation and commodification, where $\mathrm{HE}$ is presented as 'a private benefit to the individual consumer [and] a financial asset where the return on investment is seen in higher earnings upon graduation. ${ }^{, 63}$ The implementation of this debt regime is undoubtedly smoothed by the continuing orthodoxy that HE is a mechanism of social mobility. While current conditions for working-class and other non-traditional students are markedly different from those of grant-era HE, and while these conditions may affect in radical ways the choices students make over what, how and why they study, there is (for those who obtain the grades) little option today of not going to university at all.

\footnotetext{
${ }^{61}$ Devolutionary arrangements have meant that Wales, Northern Ireland and (most significantly) Scotland have some variations on this model.

62 G. Thomas Goodnight, David Hingstman \& Sandy Green, The Student Debt Bubble, Journal of Cultural Economy, 8, 1, (2015), p.83.

${ }^{63}$ Andrew McGettigan, The Great University Gamble: money, markets and the future of higher education, London, Pluto Press, 2013, p.9.
} 
This is a pre-print version of an article published as Pitcher, B (2016) 'Race, Debt and the Welfare State', New Formations, 87: 47-63.

Whether the new constituency of student consumers are buoyed by a culture of expectation that now takes HE for granted, or whether they are making modest calculations in a zero-sum game where a degree still provides protection from the lowest strata of low-paid and precarious employment, participation in UK HE has yet to stall or go into decline. Contrary to evidence from the early 2000 s suggesting that 'debt aversion' is a deterrent to HE entry at the lower end of the social spectrum, ${ }^{64} \mathrm{HE}$ entry rates of students from 'disadvantaged backgrounds' continue to rise year on year. ${ }^{65}$ The most recent application figures show that 'application rates of 18-year-olds living in poor areas in all four countries of the UK have increased to the highest levels recorded. ${ }^{66}$ Although the current UK HE debt regime has led to a fall in applications from more wealthy students, those from lower socio-economic groups 'express a strong belief in the ability of higher education to offer them greater opportunities and incomes than would otherwise be available. ${ }^{67} \mathrm{~A}$ recent typology of indebtedness amongst English students finds that the 'debt-positive' are 'disproportionately drawn from lower income families and

\footnotetext{
${ }^{64}$ Universities UK, Attitudes to Debt, 2003. Available at: http://www.universitiesuk.ac.uk/highereducation/Pages/StudentDebtSummary. aspx [6.05.15].

65 UCAS, 'Record $8 \%$ more students from disadvantaged backgrounds get into university' press release, 14 August 2014. Available at: http://www.ucas.com/news-events/news/2014/more-students-disadvantagedbackgrounds-get-university [18.08.14]. See also UCAS '2013 Application Cycle: End of Cycle Report', 2013. Available at: http://www.ucas.com/dataanalysis/key-analysis [18.08.14].

${ }^{66}$ Press Association, 'Low-income students more likely than ever to apply to university, Ucas says', Guardian, 30 January 2015. Available at: http://www.theguardian.com/education/2015/jan/30/low-income-studentslikely-apply-university-ucas [8.10.15].

${ }^{67}$ Neil Harrison, Steve Agnew and Joyce Serido 'Attitudes to debt among indebted undergraduates: A cross-national explanatory factor analysis', Journal of Economic Psychology, 46, (2015), p70.
} 
This is a pre-print version of an article published as Pitcher, B (2016) 'Race, Debt and the Welfare State', New Formations, 87: 47-63.

deprived areas. ${ }^{68}$ Whatever factors are involved here (and they are likely to be complex), it is clear for the time being at least that the self-investment sales patter of successive governments has not significantly deterred workingclass students from the accumulation of education debt.

Without playing down the negative dimensions of HE debt, we might speculate that it has given many working class students and their families a set of coordinates to navigate the otherwise difficult-to-read cultural terrain of tertiary education. There's arguably a kind of conceptual democratization at work here where the market opens up imaginative possibilities for some subjects even as it closes down their opportunities. The ideological function of indebtedness in securing the legitimacy of the HE marketplace will doubtless continue beyond the point when it does, eventually, become a significant deterrent to participation, as neoliberal restructuring manages a shift from increasingly unacceptable - and culturally opaque - criteria of exclusion (products of elitism, cultural privilege, even evaluations of 'intelligence') to a single legitimate - and, importantly, intelligible - criterion of exclusion (unaffordability). Under the levelling aegis of debt, all will be theoretically entitled to $\mathrm{HE}$, but not everyone will be in a position to purchase it.

Race is of course more than just a modality of class, and the equalitarian rhetoric of indebtedness might be said to have a specific appeal to some racialized subjects. At their inception, all HE debts are written onto clean

\footnotetext{
${ }^{68}$ Neil Harrison, Farooq Chudry, Richard Waller and Sue Hatt 'Towards a typology of debt attitudes among contemporary young UK undergraduates', Journal of Further and Higher Education, 39, 1, (2015), p94.
} 
This is a pre-print version of an article published as Pitcher, B (2016) 'Race, Debt and the Welfare State', New Formations, 87: 47-63.

slates. While the outcomes of indebtedness in HE will be radically dissimilar, the generic front end of debt relations present themselves as a universal fact of life. The bureaucracies of its debt are simple and streamlined, like the never-read click-through small print to which all young people are necessarily now familiarized through software licenses, phone contracts, or UCAS university application forms. So often when scholars of race think critically about 'colourblind' orientations to the subject our objective is to problematize white investments in the denial of racial significance, ${ }^{69}$ but of course debt also presents a figuration of racial transcendence capable of servicing the aspirations of some minority subjects who might otherwise be shut out of or marginalized within the culture and institutions of the welfare state: it is possible to visualize the debt system as an 'equal-opportunity oppressor'. ${ }^{70}$ While, because they describe equal parties to a contract, creditor-debtor relations are premised on a notion of legal equality, ${ }^{71}$ they can be said to retain an intrinsic imbalance of value in so far as they involve the extraction of interest by the creditor. By contrast there remains an identity and a semblance of equality between debtor subjects under the auspices of formally equivalent debt regimes. Student debtors, drawing on hypothetical future earnings calculated using the variable of hope, all appear to be in the same boat. Ironically, it is the very clarity of these abstracted relations of indebtedness the way they make sense outside of culture and enculturation - that helps to

${ }^{69}$ See, for example, Eduardo Bonilla-Silva, Racism Without Racists: colorblind racism and the persistence of racial inequality in America, fourth edition, Lanham, MA, 2014.

${ }^{70}$ Yates McKee, 'Debt: Occupy, Postcontemporary Art, and the Aesthetics of Debt Resistance', The South Atlantic Quarterly, 112, 4, (2013), p797.

${ }^{71}$ David Graeber, Debt: The First Five Thousand Years, New York, Melville House Publishing, 2011, p86. 
This is a pre-print version of an article published as Pitcher, B (2016) 'Race, Debt and the Welfare State', New Formations, 87: 47-63.

cover over the racialized inequalities of debt relations. While in the past unequal access to finance made 'credit equality' an issue in the politics of class, race and gender, ${ }^{72}$ contemporary HE debt is offered to all comers on scrupulously equal terms. The (failing) competitive market of HE has set tuition fees at the same rate for all institutions, and maintenance loans are of an identical value (with the exception of London weighting). In the face of the possibility that the ideal model of debtor subjectivity in UK HE might appear to discriminate between Muslims and non-Muslims, the British government has consulted and intends to legislate on a 'Sharia compliant alternative finance product' to work around Islamic objections to the charging of above-inflation interest on loans. Now even those with a theological objection have the opportunity to take on 'identical' levels of indebtedness to 'traditional' debtors. $^{73}$

Any apparent enthusiasm for higher education debt by no means invalidates protest against it. The US experience is salutary: the average AfricanAmerican student is saddled with nearly 30 per cent more debt than the average white student, ${ }^{74}$ and is as a result four times more likely to default. ${ }^{75}$

\footnotetext{
${ }^{72}$ For an overview of US debates, see Louis Hyman, Ending Discrimination, Legitimating Debt: The Political Economy of Race, Gender and Credit Access in the 1960s and 1970s, Enterprise \& Society, 12, 1, (2011), 200-232.

73 Department for Business, Innovation and Skills, Sharia-Compliant Student Finance, 2014, p6. Available at:

https://www.gov.uk/government/consultations/sharia-compliant-studentfinance [21.10.14].

${ }^{74}$ Chris Walker, 'Why Student Debt is a Race Issue, in 4 Charts', 2014. Available at: http://mic.com/articles/98392/why-student-debt-is-a-race-issuein-4-charts [21.10.14].

${ }^{75}$ Andrew Ross, Creditocracy and the case for debt refusal, New York, OR Books, 2013, p120.
} 
This is a pre-print version of an article published as Pitcher, B (2016) 'Race, Debt and the Welfare State', New Formations, 87: 47-63.

This disproportionate debt burden is being accrued in a context where the 'wealth gap ratio' between black and white in the States - which closed up a little in the early 1990 s - is now quite rapidly increasing. ${ }^{76}$ These facts pretty much speak for themselves. And yet if we focus solely on the inegalitarian outcomes that such debts inevitably accrue, it is easy to play down the potentially attractive qualities of debt regimes and the complexly generative role debt might have to play in racial formation. ${ }^{77}$ Indebtedness does not simply persuade debtor subjects to act against their own interests (however they might be defined), but could actively produce ways of thinking, acting and relating that might provide credible, desirable - even 'better' - alternatives to those they replace. While the question of defining 'interests' might appear relatively unproblematic (surely the collectivization of education debt is preferable to its individualization?) it is my contention that the self-evidence of this analysis presupposes a form of subject-state relations that has become increasingly anachronistic. To demand the restitution of an earlier entitlement - like free education - takes for granted a symbolic affinity with the citizensubject of the postwar social democratic settlement. This is an affinity that we cannot take for granted amongst anyone who grew up in neoliberal Britain, and particularly for those whose racialization already marginalizes them within dominant regimes of welfare citizenship. In so far as the uneven but undeniable victories in the struggle for racial equality in Britain have coincided - from the 1970s onwards - with the rise of neoliberalism, it seems plausible

\footnotetext{
${ }^{76}$ Pamela Brown, 'Solidarity for Reparation', Tidal, 4, 2013, pp10-11. Available at: http://tidalmag.org/issue-4-block-by-block/ [21.10.14]. 77 see Miranda Joseph, Debt to Society: Accounting for Life under Capitalism, Minneapolis, University of Minnesota Press, 2014, chapter 1.
} 
This is a pre-print version of an article published as Pitcher, B (2016) 'Race, Debt and the Welfare State', New Formations, 87: 47-63.

to suggest that the imaginative resources of neoliberal culture have with time become more available to racialized minorities than those of a fading, racially marked, social democracy. Such a shift is also consonant with the general decline in support for the welfare state amongst each successive postwar generation. $^{78}$

\section{The futurity of debt}

There is more to the potential appeal of debt than just the initial veneer of equality between debtors. Following Nietzsche, Lazzarato makes future relations central to his understanding of debt. While he is right in his estimation that enslaving debt obligations allow capitalism to exercise 'control over the future' by influencing the thinking and behaviour of the governed, ${ }^{79}$ these same debt relations might additionally be understood as producing a variety of belonging. Crucially, the future orientation of the debt relation sutures the debtor to a version of the social; obligations to the future describe an entitlement to exist and persist, if only to repay debt. While the futurity of debt may also be rightly problematized for the normative baggage it implies, ${ }^{80}$ the temporal structure of debt culture offers a model of collectivity very different from backward-looking (racially static if not racially homogenous)

\footnotetext{
${ }^{78}$ See Bobby Duffy, Suzanne Hall, Duncan O'Leary and Sarah Pope, Generation Strains: A Demos and Ipsos MORI report on changing attitudes to welfare, London, Demos, 2013. Available at: http://www.demos.co.uk/publications/generationstrains [21.10.14].

${ }^{79}$ Lazzarato, 2012, op. cit., p45. For an empirical account of some of the ways in which this can be experienced, see Joe Deville, Lived Economies of Default: Consumer Credit, Debt Collection and the Capture of Affect, London, Routledge, 2015.

${ }^{80}$ See, for example, the feminist and queer theory critiques of austerity politics outlined in Heather Latimer, 'The Straight Line: Sexuality, Futurity, and the Politics of Austerity', ESC: English Studies in Canada, 29, 4, (2013), pp21-4.
} 
This is a pre-print version of an article published as Pitcher, B (2016) 'Race, Debt and the Welfare State', New Formations, 87: 47-63.

logics of community. As Richard Dienst has suggested, indebtedness

'articulates the historicity of life, that is, life insofar as it becomes social and is lived in common'. ${ }^{81}$

The moral onus of indebtedness is likewise future-facing, and it is easy to see how the obligation on debtor subjects to prove themselves and make good their debt is preferable to being judged wanting from the outset in a racialized regime of welfare citizenship. Even when the future to which debt binds is circumscribed and reduced by that debt - when in a sense it 'belongs' to the creditor - it is nevertheless a future on which debtor subjects have an unequivocal claim. Debt's negative entitlement hardly paints a rosy picture, but neoliberal rationality makes the future that debt describes a plausible one, and the possibility of against-the-odds success sweetens more realist assessments that some future is better than no future at all. Debt's hardships are leavened by this concoction of realism and hope. In the case of HE, the threat of abject alternatives couples with education's obdurate tendency to channel future-oriented desires for social mobility and self-improvement (a trajectory that for minoritized subjects parallels and in part feeds off the teleological character of anti-racist desire). While Lazzarato's intention is to disparage when he writes that solvency has become a measure of morality, ${ }^{82}$ the subsumption of morality to economic measurement can be read as another universalizing and simplifying process that transforms opaque and exclusionary forms of cultural distinction into 'inclusionary' economic relations.

\footnotetext{
${ }^{81}$ Richard Dienst, The Bonds of Debt: borrowing against the common good, London, Verso, 2011, p147.

82 Lazzarato, 2012, op. cit., p58.
} 
This is a pre-print version of an article published as Pitcher, B (2016) 'Race, Debt and the Welfare State', New Formations, 87: 47-63.

When debt takes on an ontological role in the constitution of social relations, its significance exceeds any empirical measure of impoverishment. If it is out of debt that we derive legitimacy, self-respect and (however paradoxically) entitlement, then the brute economics of debt's burden become relegated as a secondary concern.

These possibilities that inhere in the futurial orientation of debt do not negate the long-recognized tendencies Lazzarato foregrounds for debt to induce forms of self-repressive subjectivation. It is quite plausible that in the long run the shame of debt wins out, but it is equally possible that debt's enhanced role in 'a new consumer culture of social entitlement' is significantly loosening the moral (and linguistic) relationship between debt and guilt. ${ }^{83}$ It is worth entertaining the likelihood that in some circumstances debt may open up as well as close down possibilities for some subjects in neoliberal Britain. Could debt provide the ground to a qualitatively new politics of belonging that is not entirely undermined by the inequalities it so evidently produces? Critique of the latter does not diminish the former: while it's impossible to fault the economic logic of calls for debt resistance pioneered in the US by groups like Strike Debt, ${ }^{84}$ we might question the extent to which debt resistance alone is capable of furnishing the ontological ground that debt relations provide. In turn, this may play a part in explaining why it is that in the US there is a 'frequent impression that the political project of debt resistance is somehow

\footnotetext{
${ }^{83}$ Kenneth Dyson, States, Debts and Power, Oxford, Oxford University Press, 2014, pp78, 68.

${ }^{84}$ strikedebt.org
} 
This is a pre-print version of an article published as Pitcher, B (2016) 'Race, Debt and the Welfare State', New Formations, 87: 47-63.

limited to privileged white people'. ${ }^{85}$ In Lazzarato's own terms, indebtedness can be said to involve a 'mixed semiotics', ${ }^{86}$ processing debtor subjectivity in terms that are both signifying and asignifying, by degrees simultaneously molar and molecular. ${ }^{87}$ Effective protest against and alternatives to indebtedness must recognize and operate on both representational and nonrepresentational terrain. Like any viable alternative to the political orthodoxies of austerity Britain, they must succeed in capturing the investments of subjects for whom the narratives, dispositions, practices and styles of neoliberalism presently delineate the most attractive and convincing of futures.

\section{Post-national futures}

However contradictory as political projects, the futurial orientation of neoliberal debt relations resonates in some respects with the foundational ethos of the postwar welfare state. To look back at this moment three quarters of a century ago is sometimes to lose sight of its future-facing character, where the welfare state did not describe something achieved but rather the hope, possibility and promise of a programme for the future. If we use neoliberal debt relations to think about the terms with which we might reimagine the welfare state, we draw attention to the temporalities of the present-future. Debt serves to make sense of social relations and models 'investment' in a shared future. Such a perspective helps to shake off the implicit investments of welfare imaginaries in the mythic, racialized ground of national belonging, and turns us towards

\footnotetext{
${ }^{85}$ McKee, op cit., p. 797

${ }^{86}$ Lazzarato, 2014, op. cit., p95.

87 Ibid., p124.
} 
This is a pre-print version of an article published as Pitcher, B (2016) 'Race, Debt and the Welfare State', New Formations, 87: 47-63.

the temporally specific place of the present. The claim to welfare is then absolutely not rooted in history and genealogy, but in the contingent situation of the present time and place. The demythologization of welfare is a naming of needs, rights and obligations that makes a clear break with notions of accrued generational service to the nation, to versions of community, social or cultural solidarity or belonging that still subtly inform dominant articulations of welfare citizenship. To follow the lead modelled by neoliberal debt helps us to conceive of welfare in a present where there is no question of who is more or less entitled, more or less deserving of better or preferential treatment.

The problem, of course, is that the universal welfare model implied here is a unpopular one, and those seeking to stem declining support for the British welfare state still tend to look to practices that return us to an implictly racialized terrain of differential entitlement based on differential contributions. ${ }^{88}$ There are no easy answers to the problem of developing progressive political imaginaries to work against neoliberalism's continuing hold on austerity Britain, but it is my argument here that thinking about debt's appeal provides us with an opportunity to understand what is insufficient about such backward-looking solutions. The straightforward 'reassembly' of the 'dismantled' 'golden age' British welfare state is an unviable project, and not only on account of the unacceptability of its tacit racial exclusions. Like the material/symbolic defences of national integrity that Wendy Brown describes

\footnotetext{
${ }^{88}$ See, for example, Duncan O'Leary, Something for something: restoring a contributory principle to the welfare state, London, Demos, 2013.
} 
This is a pre-print version of an article published as Pitcher, B (2016) 'Race, Debt and the Welfare State', New Formations, 87: 47-63.

as symptomatic of the dissolution of nation-state sovereignty, ${ }^{89}$ the idealized postwar welfare state and the Marshallian model of social citizenship that comes with it are in some respects little more than comforting phantoms, produced by a nostalgia for a political imaginary whose efficacy has long since passed. Longstanding 'connections forged between nationality, nationness and citizenship' have been subject to an 'unbundling', ${ }^{90}$ and those of us who want to 'defend' the idea of the welfare state are kidding ourselves if we think that we can (or should) just bundle these up together again as if the profound transformations of the last 70 odd years could be written off or put into reverse.

What might stand in as viable successors and alternatives still remains to be developed, but it seems clear that the task of imagining the 'culture, habits, virtues and practices of participatory democracy' in 'our age of migration' requires a 'thinner' embedding in ethno-national norms. ${ }^{91}$ Again, neoliberal debt does not provide an answer in itself, but it gestures in a direction beyond the realm of dominant welfare imaginaries, of both left and right. While neoliberalism is necessarily stabilized and expressed in localized (typically national) cultural and political formations, ${ }^{92}$ it simultaneously possesses a transnational logic that is not necessarily attached to or invested in any

\footnotetext{
${ }^{89}$ Wendy Brown, Walled States, Waning Sovereignty, New York, Zone Books, 2010.

90 John Clarke, Kathleen Coll, Evalina Dagnino and Catherine Neveu, Disputing Citizenship, Bristol, Policy Press, 2014, p120.

${ }^{91}$ Viet Bader, 'Institutions, Culture, and Identity of Transnational Citizenship: How Much Integration and "Communal Spirit" is Needed?', in C. Crouch, K. Eder and D. Tambini (eds) Citizenship, Markets and the State, Oxford, Oxford University Press, 2001, p208.

${ }^{92}$ Clarke et al., 2014, op. cit.
} 
This is a pre-print version of an article published as Pitcher, B (2016) 'Race, Debt and the Welfare State', New Formations, 87: 47-63.

particular iteration. The model of markets and consumer debt operates easily within a global, transnational framework. Debt produces a familiar, universally translatable set of reference points, particularly for increasing numbers of us who self-identify in diasporic and transnational terms. Rather than think about minority subjects only as the most acute victims of neoliberalism's incursions on the welfare state, we might consider how they may also possess some of the orientations and conceptual resources with which to develop forms of rights and entitlement beyond national(ist) regimes of welfare citizenship. ${ }^{93}$

The once culturally specific model of the 'American dream' has mutated to become a lingua franca of global neoliberal aspiration, and the validity of narratives of indebtedness is confirmed and consolidated within a global frame where the private provision of social goods like HE is rapidly expanding at the expense of the public sector. ${ }^{94}$ Even as debt serves as an instrument of control, it remains a marker of capitalist incorporation, distinguishing debtor subjects from the 'three-quarters of humanity' who remain 'too poor for debt'. ${ }^{95}$ There are lessons that we might learn from debt relations in the global South, which after all has had 'a rather longer (and harsher) exposure' than the North

\footnotetext{
${ }^{93}$ In rather less positive terms, the experiences and orientations of those who have long been marginalized by dominant regimes of welfare citizenship provide a window into the general outlook for the customers of the welfare state in austerity Britain, as government spending is forecast to decline during the period of the 2015-20 parliament to its lowest level since the 1930s (Office for Budgetary Responsibility, Economic and Fiscal Outlook: December 2014, London, The Stationery Office, 2014, p80).

${ }^{94}$ Philip G. Albach, Liz Reisberg and Lauren E. Rumbley, Trends in Global Higher Education: Tracking an Academic Revolution, Paris, UNESCO, 2009, chapter 6.

${ }^{95}$ Gilles Deleuze, 'Postscript on the Societies of Control', October, 59, (1992), p6.
} 
This is a pre-print version of an article published as Pitcher, B (2016) 'Race, Debt and the Welfare State', New Formations, 87: 47-63.

to the rigours of fiscal austerity. ${ }^{96}$ The global South has not only served as a 'petri dish' for neoliberal experiments now being exported to Euro-America. Unshackled from the teleology of European modernisation, southern modernities are altering planetary practices and producing new 'idioms of work, time, and value'. The minimally regulated, highly flexible informal economies of the global south foreshadow Euro-American futures. ${ }^{97}$ The moment of globalized neoliberal capitalism threatens longstanding political imaginaries precisely because it requires us to contemplate some radically post-national forms of political organization. Its logic continues to be resisted in welfare debates on the left for the legitimate reason that welfare citizenship within a global, transnational frame seems such a unrealistic and unfeasibly cosmopolitan project in the current historical moment. Recent judgments against 'economically inactive' EU migrants suggest a retrenchment of supranational welfare citizenship within austerity Europe, ${ }^{98}$ and the current political opportunities to reverse this trend seem slight. And yet it's clear that the forms of welfare subjectivity prefigured by neoliberal debt regimes also delineate emergent possibilities for post-national political projects of social welfare, social democracy, and economic redistribution.

\section{Learning from neoliberalism}

\footnotetext{
96 John Clarke and Janet Newman, 'The alchemy of austerity', Critical Social Policy, 32, 3, (2012), p300.

${ }^{97}$ Comaroff and Comaroff, op. cit., p13.

${ }^{98}$ Barbara Wesel, 'Jobless immigrants can be barred from receiving social welfare', 2014. Available at: http://www.dw.de/jobless-immigrants-can-bebarred-from-receiving-social-welfare/a-18057474 [01.12.14].
} 
This is a pre-print version of an article published as Pitcher, B (2016) 'Race, Debt and the Welfare State', New Formations, 87: 47-63.

To be quite clear, it is not my suggestion here that neoliberalism's creation of debtor subjects should be applauded as an unequivocally positive development in the struggle against racialized disadvantage, discrimination, and subjugation. The displacement of publics by markets, the privatization of social goods and the desperately unequal burden of individualized debt is not somehow mitigated by the way it might model racial equality and hope for the future, however convincingly it might do this. The racial politics of neoliberal debt can also work to reinscribe and reinforce the terms of racial difference, such as through the financialization of 'subprime subjects' in contemporary 'technologies of racial finance'. ${ }^{99}$ Debt culture is by no stretch of the imagination a straightforward 'answer' to the inequalities of our profoundly racialized social formations. What I'm trying to suggest, nevertheless, is that it is a dangerous mistake to ignore the possibility of debt's resonant appeal in our 'defence' of that which it replaces and displaces. I'm suggesting that there might be lessons we can learn from a clear-sighted consideration of neoliberal debt culture, particularly as it appears to tackle (if only on a 'symbolic' level) the inequalities that persist in dominant articulations of welfare citizenship. While it is important to be cautious of lending capitalism too much causal power in understanding the complexity of racial formation, ${ }^{100}$ its potential to level, subvert and antiquate entrenched cultural hierarchies has of course been long recognized, ${ }^{101}$ and what might be glossed as the forces of

\footnotetext{
99 Zenia Kish and Justin Leroy, Bonded Life, Cultural Studies, 29, 5-6, (2015), 630-651.

${ }^{100}$ Ben Pitcher, 'Race and Capitalism Redux', Patterns of Prejudice, 46, 1, (2012), pp1-15.

${ }^{101}$ Karl Marx and Freidrich Engels, The Communist Manifesto, Oxford, Oxford University Press, 1992.
} 
This is a pre-print version of an article published as Pitcher, B (2016) 'Race, Debt and the Welfare State', New Formations, 87: 47-63.

neoliberal globalization suggest some powerful contemporary alternatives to welfare citizenship from which we might also stand to learn.

In her account of welfare and citizenship in Italy, Andrea Muelebach suggests that neoliberal morality, as practiced in acts of charity, is best seen not as the straightforward product of market rationality, but as existing in 'productive tension' with it. If it is right to suggest that 'neoliberalism is a force that can contain its negation', 102 then critical projects interested in 'defending' the welfare state might have much to learn from its 'dismantling'. The abstract, universal and impersonal qualities of debt produce forms of neoliberal society and citizenship relations that are in certain respects symbolically less exclusive than the social and citizenship relations they displace. To oppose what is so destructive and divisive in neoliberal capitalism requires an openness that we might borrow from it too.

This point might be expressed in more specific and immediate terms. If we remain in thrall to the model of the 'golden age' and continue as I have suggested to be caught up with a refusal to address the racially exclusionary character of welfare citizenship, then we begin to consolidate a political imaginary that potentially lines up the exponents and champions of the welfare state against the predilections and orientations of some minoritized citizens who may find meaning in a different set of reference points. When racialized minorities are posited as having most to lose from the dismantling of the welfare state, it is easy, but wrong, to suggest that they must be grateful

$\overline{102}$ Muelebach, op. cit., pp24-5. 
This is a pre-print version of an article published as Pitcher, B (2016) 'Race, Debt and the Welfare State', New Formations, 87: 47-63.

to others in their actions to protect it, or that their own ambivalence towards it or rational pursuit of alternative scenarios should be held against them (and in doing so rerunning a theoretically anachronistic economic reductionism that can only understand race and racism as epiphenomena of class struggle). By reinforcing a racialized model of welfare citizenship, we also reduce the constituency of those who might be rallied to 'protect', 'defend', rework and reimagine the welfare state. 